\title{
Erratum to: Public Regulation of Tumor Banks
}

\author{
Xavier Bioy
}

\section{Erratum to:}

X. Bioy (ed.), Public Regulation of Tumor Banks, https://doi.org/10.1007/978-3-319-90563-1

This online version of this book was inadvertently published without a Copyright remark about the French version in the copyright page. This has now been rectified. 